\title{
ANALISIS FAKTOR-FAKTOR YANG MEMPENGARUHI KEPUTUSAN MAHASISWA ASAL KABUPATEN SUMBAWA DALAM MEMILIH PERGURUAN TINGGI UNIVERSITAS TEKNOLOGI SUMBAWA
}

\author{
The Analysis of Affecting Factors of Students Decision from Sumbawa Regency \\ in Choosing Sumbawa University of Technology \\ ${ }^{1}$ Fahmi Budi Raharjo, ${ }^{2}$ Fendy Maradita, ${ }^{3}$ Hanifa Sri Nuryani \\ Manajemen, Fakultas Ekonomi dan Bisnis, \\ Universitas Teknologi Sumbawa \\ Jl. Raya Olat Maras, Batu Alang, Moyo Hulu, Kabupaten \\ Sumbawa \\ Email : fahmibudi1@gmail.com
}

\begin{abstract}
Abstrak
Budi Raharjo, Fahmi, (2020), Analisis Faktor-Faktor yang Mempengaruhi Keputusan Mahasiswa Asal Kabupaten Sumbawa Dalam Memilih Perguruan Tinggi Universitas Teknologi Sumbawa. Skripsi, Program Studi Manajemen, Fakultas Ekonomi dan Bisnis, Universitas Teknologi Sumbawa, Pembimbing: (I) Fendy Maradita, M.M. (II) Hanifa Sri Nuryani,M.M. Penelitian ini bertujuan untuk mengetahui faktor-faktor yang mempengaruhi keputusan mahasiswa asal Kabupaten Sumbawa dalam memilih perguruan tinggi Universitas Teknologi Sumbawa, Landasan Teori penelitian yang digunakan yaitu bauran pemasaran yang disebut 7P (Product, Price, Promotion, Place, People, Physical evidence and Process) dan faktor-faktor pengambilan keputusan ( Budaya, Sosial, Psikologis). Populasi adalah seluruh mahasiswa asal Kabupaten Sumbawa yang kuliah di Universitas Teknologi Sumbawa dari angkatan 2017 hingga angkatan 2019 dengan sampel sebanyak 21 mahasiswa dari setiap perwakilan pembagian daerah di Kabupaten Sumbawa. Penelitian ini dilakukan dengan wawancara semi terbuka dengan pertanyaan yang akan mendalam untuk mendapat jawaban yang diharapkan oleh peneliti. Hasil dari penelitian ini adalah mahasiswa asal Kabupaten Sumbawa memilih perguruan tinggi Universitas Teknologi Sumbawa karena beberapa hal yaitu program studi yang langka dan bervariasi, lokasi kampus, prestasi mahasiswa, lulusan pengajar, alumni kampus, beasiswa dan jarak yang dekat menurut dari para informan.

Kata kunci : Faktor Keputusan, Bauran Pemasaran. Keputusan Pembelian
\end{abstract}

\begin{abstract}
Budi Raharjo, Fahmi, 2020, The Analysis of Affecting Factors of Students Decision from Sumbawa Regency in Choosing Sumbawa University of Technology. Thesis, Majoring in Economic Management, Economic and Business, Sumbawa University of Technology, Advisor: (I) Fendy Maradita, M.M. (II) Hanifa Sri Nuryani, M.M. This study aims to analyze the affecting Factors of Students Decision from Sumbawa Regency in Choosing Sumbawa University of Technology, the foundation of this study using marketing mix which is called 7P (Product, Price, Promotion, Place, People, Physical evidence and Process) and decision making factors (Culture, Social, Psychological). the population are all students in Sumbawa University Technology who came from Sumbawa Regency from the class of 2017 to 2019 which sample are around 21 students from each regional representatives in Sumbawa Regency. This study was conducted with a semi-open interview with depth questions to get the answers who was expected by the researcher. The result of this study shows that the students from Sumbawa Regency chose Sumbawa University of Technology because of several things like the study programs are rare and varied, the campus location, the student achievement, the lecturer graduates, the campus alumni, the scholarships and the close distance according to the informants.
\end{abstract}


Keywords : Decision Factor, Marketing Mix, Purchase Decision

\section{PENDAHULUAN}

Pendidikan merupakan bentuk dari investasi jangka panjang (long-term investment), artinya bahwa investasi pada bidang sumber daya manusia memang tidak segera bisa dinikmati hasilnya. Perguruan Tinggi merupakan salah satu bagian penting dalam dunia pendidikan yang ikut bertanggung jawab dalam upaya mencerdaskan kehidupan bangsa (Wijaya, 2012).

Oleh karena itu penting merumuskan strategi pemasaran jasa pendidikan yang optimal agar dapat memenangkan persaingan antar pendidikan tinggi dan untuk meningkatkan akselerasi peningkatan kualitas serta profesionalisme manajemen pendidikan tinggi (Margaretha dan Nilo, 2016), yakni dengan memahami sikap dan faktor-faktor yang menjadi pertimbangan calon mahasiswa memilih perguruan tinggi swasta melalui konsep marketing mix (Suparto, 2014).

Philip Kotler dan Kevin Lane Keller (2009) mengemukakan bahwa perusahaan tidak hanya harus berhubungan secara konstruktif dengan pelanggan, pemasok, dan penyalur, tetapi juga harus berhubungan dengan sejumlah besar masyarakat yang berminat. Hubungan masyarakat meliputi berbagai program untuk mempromosikan atau melindungi citra atau produk individual perusahaan. Hubungan masyarakat sangat peduli terhadap beberapa tugas pemasaran antara lain membangun citra, mendukung aktifitas komunikasi lainnya, mengatasi berbagai permasalahan dan isu yang ada, memperkuat posisi sebuah perusahaan, mempengaruhi publik yang spesifik, dan mengadakan peluncuran untuk sebuah produk jasa baru.

Pengaruh pemasaran hadir untuk mengidentifikasi strategi pemasaran perusahaan, mengidentifikasi taktik pemasaran perusahaan, dan mengidentifikasi nilai pemasaran perusahaan, ada 6 bagian dalam pengaruh pemasaran yaitu :

1) Segmentasi adalah proses membagi pasar menjadi segmen-segmen yang lebih kecil berdasarkan karakteristik serupa dari perilaku pelanggan, dan kemudian menentukan segmen-segmen mana yang mau kita layani.

2) Targeting adalah proses melakukan evaluasi dari daya tarik setiap segmen pasar dan kemudian memilih satu atau dua segmen untuk dimasuki.

3) Positioning adalah perancangan penawaran dan citra perusahaan ke dalam benak konsumen.
4) Diferensiasi adalah kebijakan perusahaan yang mengintegrasikan konten (content), konteks (context), dan infrastruktur (infrastructure) dari apa yang ditawarkan kepada pelanggan.

5) Merek (brand) adalah aset yang menciptakan nilai bagi pelanggan dengan meningkatkan kepuasan dan menghargai kualitas.

6) Ekuitas merek (Brand Equity) adalah frase yang mendeskripsikan nilai dari suatu merek.dengan demikian perusahaan dapat menghasilkan lebih banyak lagi uang dari produk yang memakai suatu merek dibandingkan produk tanpa merek.

Peningkatan jumlah Mahasiswa Asal daerah yang meneruskan pendidikan dikampus lokal mempunyai beberapa hal yang sangat membangun daerah tersebut seperti yang tertulis bahwa IPM dibentuk oleh tiga dimensi dasar, yaitu umur panjang dan hidup sehat (a long and healthy life), pengetahuan (knowledge), dan standard hidup layak (decent standard of living) (http://www.bps.go.id 2019). Dimana Pengetahuan diukur melalui indikator Rata-rata Lama Sekolah dan Harapan Lama Sekolah. Rata-rata Lama Sekolah (RLS) adalah rata-rata lamanya (dalam tahun) penduduk usia 25 tahun ke atas yang telah atau sedang menjalani pendidikan formal. Pada dasarnya mahasiswa atau seseorang yang meneruskan pendidikan pada jenjang Universitas akan kembali untuk membangun kampung halaman nya kembali.

Universitas Teknologi Sumbawa berawal dari pendirian Sekolah Tinggi Teknologi Teknik Sumbawa (ST3S) pada tanggal 21 Mei 2012, yang menjadi sekolah tinggi teknik pertama di pulau Sumbawa. ST3S yang berada di bawah naungan Yayasan Dea Mas, memiliki 4 Program studi yakni program studi teknik metalurgi, program studi teknik mesin, program studi teknik informatika dan program studi teknobiologi. Pendirian ST3S dilatarbelakangi oleh besarnya potensi sumberdaya alam kabupaten Sumbawa berupa sumber daya mineral, pertanian, perkebunan dan perikanan, sementara ketersediaan tenaga professional di bidang keteknikan sangat minim, untuk itulah ST3S membuka program studi yang relatif langka di Provinsi NTB maupun di kawasan Indonesia Timur.

Tidak lama setelah mendirikan ST3S, Yayasan Dea Mas (lembaga penyelenggara ST3S) kembali menginisiasi institusi pendidikan baru yang dinamakan Sekolah Tinggi IImu Ekonomi (STIE) Sumbawa. STIES didirikan 


\section{JURNAL MANAJEMEN DAN BISNIS VOL. 02 NO.02 2019}

Jurnal.uts.ac.id

\begin{tabular}{|c|c|c|}
\hline No & Tahun & $\begin{array}{c}\text { Jumlah Mahasiswa asal Kab. } \\
\text { Sumbawa }\end{array}$ \\
\hline 1 & 2017 & 390 \\
\hline 2 & 2018 & 536 \\
\hline 3 & 2019 & 740 \\
\hline
\end{tabular}

dengan harapan dapat menjadi solusi atas tingginya kebutuhan terhadap profesional dibidang program manajemen dan keuangan. STIES rencananya akan menyelenggarakan pendidikan strata satu dengan 2 program studi yakni akuntansi dan manajemen keuangan.

Dalam proses pengajuan izin ke Direktorat Jenderal Pendidikan Tinggi Kementerian Pendidikan dan Kebudayaan, Yayasan Dea Mas mengajukan izin pendirian ST3S dan STIES secara bersamaan. Atas saran dari Dikti, selanjutnya ST3S dan STIES digabungkan usulan perizinannya menjadi Universitas. Setelah melalui seluruh tahapan dan ketentuan yang menjadi syarat izin pendirian sebuah perguruan tinggi, baru pada tanggal 14 Maret 2013, diterbitkanlah keputusan Menteri Pendidikan dan Kebudayaan Republik Indonesia Nomor 65/E/O/2013 tentang Izin Pendirian Universitas Teknologi Sumbawa (UTS) di Kabupaten Sumbawa Provinsi Nusa Tenggara Barat pada tanggal 22 April 2014 Mendikbud RI mengeluarkan Surat Nomor 65/E/O/2014 yang ditujukan kepada Yayasan Dea Mas sebagai Penyelenggara. Universitas Teknologi Sumbawa secara keseluruhan jumlah total program studi saat ini menjadi 14. Yaitu: Teknik Metalurgi dan Material, Teknik Mesin, Teknik Informatika, Teknik Sipil, Teknik Elektro, Teknik Industri, Bioteknologi, Teknologi Industri Pertanian, Teknologi Hasil Pertanian, Akuntansi, Manajemen, Ekonomi Pembangunan, IImu Komunikasi, dan Psikologi.( https://uts.ac.id 2019)

Universitas Teknologi Sumbawa dalam perjalanan kurun waktu 3 tahun terakhir jumlah mahasiswa asal Kabupaten Sumbawa mengalami kenaikan yang cukup signifikan dari tahun ke tahun yang diketahui ada satu fakta bahwa mahasiswa asal Sumbawa mulai tertarik oleh kampus yang berlabel lokal, ada beberapa hal yang mempengaruhi siswa asal Kabupaten Sumbawa mulai tertarik dikarenakan promosi langsung kepada sekolah-sekolah di wilayah Kabupaten Sumbawa dimulai dari Kecamatan Alas Barat hingga Kecamatan Tarano, atau dorongan dari orang tua yang tidak menginginkan anaknya jauh-jauh untuk kuliah atau karena Kampus Universitas Teknologi Sumbawa menawarkan promosi beasiswa khusus bagi Calon Mahasiswa asal Kabupaten Sumbawa seperti yang terpaparkan data pada tabel 1.1
Tabel 1.1 Mahasiswa UTS Asal Kabupaten Sumbawa

Tabel diatas menunjukkan dari tahun 2017 hingga 2019 ada satu fenomena bahwa mahasiswa asal Kabupaten Sumbawa semakin meningkat jumlahnya yang melanjutkan studi pendidikan di Perguruan Tinggi Universitas Teknologi Sumbawa, bahkan pada tahun 2019 mahasiswa asal Kabupaten Sumbawa cukup melonjak dibandingkan dengan jumlah mahasiswa berasal dari luar Kabupaten Sumbawa.

Fenomena selanjutnya yaitu kampus Universitas Teknologi Sumbawa melakukan berbagai cara agar dapat dikenal oleh semua lapisan masyarakat, kita melihat poster/baliho terpasang dimana-mana khususnya di Kabupaten Sumbawa yang semakin menarik, Prestasi Mahasiswa dari tahun ke tahun semakin meningkat baik dari bidang akademik maupun non-akademik, kuota beasiswa semakin meningkat dan penambahan fasilitas atau infrastruktur kampus semakin menambah dengan sejalannya umur kampus Universitas Teknologi Sumbawa.

Keberhasilan tersebut baik karena keberhasilan promosi dari pihak UPT PMB yang memasarkan kampus datang ke setiap sekolah dengan melihat kenaikan dari segi lulusan, prestasi maupun yang ditawarkan atau bahkan karena tawaran beasiswa khusus calon mahasiswa asal Kabupaten Sumbawa akan berdampak dengan bertambahnya minat dan jumlah mahasiswa dari setiap tahunnya.

Berdasarkan dari latar belakang maka penulis tertarik untuk melaksanakan suatu penelitian tentang Analisis Faktor-Faktor yang Mempengaruhi Keputusan Mahasiswa Asal Kabupaten Sumbawa dalam Memilih Perguruan Tinggi Universitas Teknologi Sumbawa.

Dari latar belakang masalah yang telah diuraikan maka rumusan masalah sebagai berikut:

1 Bagaimana Faktor-Faktor yang memengaruhi keputusan mahasiswa asal Kabupaten Sumbawa dalam memilih perguruan tinggi Universitas Teknologi Sumbawa?

\section{METODOLOGI}

\section{Pendekatan dan Jenis Penelitian}

Penelitian ini menggunakan metode deskriptif kualitatif. Metode yang digunakan adalah metode diskriptif analisis, yaitu penelitian yang berusaha menggambarkan suatu permasalahan yang dikaji mengenai fenomena. Metode ini digunakan untuk mendiskriptifkan atau menjelaskan peristiwa yang ada pada masa 
sekarang, termasuk dalam metode ini adalah studi kasus, survey, studi pengembangan dan studi korelasi. Penelitian deskriptif merupakan penelitian yang dimaksudkan untuk mengumpulkan informasi mengenai status suatu gejala yang ada, yaitu keadaan gejala menurut apa adanya pada saat penelitian dilakukan. Seperti halnya penelitian model"Pengukuran Sesudah Kejadian" (PSK), penelitian deskriptif tidak memerlukan administrasi atau pengontrolan terhadap sesuatu perlakuan ( Arikunto 2010).

Hidayat (2010) penelitian deskriptif adalah sebuah penelitian yang lebih luas dalam penggunaan data-datanya. Luas disini lebih condong pada analisa yang panjang dari ujung awal sampai akhir, penyelesaian dalam metode penelitian deskriptif inilah menyebabkan seseorang harus memiliki komitmen yang kuat dari teori sampai ketika terjun di lapangan.

Punaji (2010) Penelitian deskriptif adalah metode riset yang memiliki tujuan guna menjelaskan secara spesifik peristiwa sosial dan alam. Kespesifikan pengunaan teori inilah menyebabkan alasan bahwa penelitian deskriptif bisa mempergunakan data berupa angka-angka yang ada dalam penelitian kuantitatif dan katakata yang lebih condong dalam penelitian kualitatif. Pada penelitian ini , survei ini dilakukan kepada mahasiswa Universitas Teknologi Sumbawa yang berasal Kabupaten Sumbawa.

Tipe wawancara yang digunakan yaitu wawancara semi terstruktur dimana tetap dalam prosedur pertayaan wawancara akan tetapi bisa menggali lebih dalam dari pihak informan.

Ukuran dari sampel yang akan dijadikan obyek penelitian ditentukan dengan pendekatan snowball sampling yang dimana dapat dilakukan secara bertahap dengan wawancara mendalam. Dalam wawancara informan, seorang interviewer harus memiliki kejujuran, kesabaran, rasa empati, dan semangat yang tinggi dengan tujuan untuk menghasilkan data valid yang dibutuhkan. Wawancara mendalam dilakukan dengan mempersiapkan sejumlah daftar pertanyaan. Umumnya wawancara lapangan ini memiliki karakteristik awal dan akhir yang tidak terlihat jelas. Pertanyaan yang diajukan disesuaikan dengan kondisi dan situasi di lapangan. Wawancara lebih banyak bersifat informal dan fleksibel, mengikuti norma yang berlaku pada setting lokal, kadang diselipkan dengan candatawa yang dapat mencairkan suasana dan membina hubungan yang erat serta meningkatkan kepercayaan individu yang diteliti.

Dalam setiap pembagian wilayah Peneliti menetapkan 5 - 7 mahasiswa sebagai informan dalam penelitian ini dengan melihat dimana titik jenuh/dari informasi yang didapatkan oleh peneliti. Dimana dari setiap pembagian wilayah di tetapkan satu informan kunci yaitu yang dimana lebih mempunyai wawasan yang dalam, dimana peneliti mendapatkan informasi detail dalam mencari data nya, dan ditambah informan pendukung yang bisa diarahkan oleh informan kunci demi mendukung hasil dari informan kunci. Peneliti membagi menjadi tiga bagian wilayah dengan harapan besar dapat objektif dalam mendapatkan informasi dari berbagai wilayah yang telah di bagian masingmasing.

Dalam penelitian ini informan dari Mahasiswa Universitas Teknologi Sumbawa dibagi dalam Empat Bagian dalam rentang wilayah Kabupaten Sumbawa yaitu :

Tabel 2.6 Pembagian wilayah di Kabupaten Sumbawa

\begin{tabular}{|c|c|c|c|}
\hline Barat & Timur & Tengah & Selatan \\
\hline $\begin{array}{l}\text { Alas } \\
\text { barat }\end{array}$ & Tarano & Sumbawa & Lenangguar \\
\hline Alas & Empang & $\begin{array}{l}\text { Moyo } \\
\text { hulu }\end{array}$ & Ropang \\
\hline Buer & Labangka & Moyo hilir & lantung \\
\hline Utan & Plampang & $\begin{array}{l}\text { Moyo } \\
\text { utara }\end{array}$ & Orong telu \\
\hline \multirow[t]{3}{*}{ Rhee } & Maronge & Untir iwes & lunyuk \\
\hline & Lape & $\begin{array}{l}\text { Labuan } \\
\text { badas }\end{array}$ & \\
\hline & Lopok & Batu lante & \\
\hline
\end{tabular}

(sumber data bps.go.id)

\section{TEKNIK ANALISIS DATA}

Sugiyono (2016) mengatakan bahwa analisis data adalah proses mencari dan menyusun secara sistematis data yang diperoleh dari hasil sebuah wawancara, catatan lapangan, dan dokumentasi, dengan cara mengorganisasikan data ke dalam kategori, menjabarkan ke dalam unit-unit, melakukan sintesa, menyusun ke dalam pola, memilih mana yang penting dan yang akan dipelajari, dan membuat kesimpulan sehingga mudah dipahami oleh diri sendiri maupun orang lain.

\section{HASIL DAN PEMBAHASAN}

\section{Produk}

Produk merupakan kombinasi barang dan jasa yang ditawarkan seseorang atau lembaga untuk memenuhi kebutuhan dan keinginan pasar serta produk merupakan segala sesuatu baik itu berwujud ataupun tidak berwujud yang 


\section{JURNAL MANAJEMEN DAN BISNIS VOL. 02 NO.02 2019}

Jurnal.uts.ac.id

ditawarkan kepada pasar sebagai pemenuhan kebutuhan atau pemenuhan kepuasan keinginan konsumen.

Perguruan tinggi pada umumnya selalu menawarkan apa yang dapat menjadikan satu keunggulan tersendiri atau sesuatu yang dapat menjadi daya tarik satu kampus tersebut, yang tidak terlepas dari berbagai aspek seperti menawarkan gedung perkuliahan, berbagai bidang program studi, akreditasi kampus, infrastruktur lingkungan kampus, Organisasi mahasiswa dan lain sebagainya, begitu pula dengan kampus Univesitas Teknologi Sumbawa yang setiap tahunnya selalu menawarkan kepada masyarakat khususnya bagi siswa kelas 3 SMA atau sederajat agar selanjutnya memilih Kampus Universitas Teknologi Sumbawa sebagai perguruan tinggi bagi masyarakat Sumbawa.

Kampus Universitas Teknologi Sumbawa menawarkan 3 wilayah gedung perkuliahan bagi seluruh calon mahasiswanya yaitu wilayah Gedung Ekonomi, Wilayah Gedung Karim dan Wilayah Gedung Rektorat, kampus Universitas Teknologi Sumbawa juga menawarkan 14 Program Studi yang diantaranya menjadi program studi yang langka atau susah untuk mendapatkannya khususnya pada wilayah BaliNusa Tenggara seperti program studi Bioteknologi, Industri, Metalurgi dan Psikologi. Disamping itu juga menawarkan berbagai kegiatan mahasiswa untuk mendukung keaktifan mahasiswa seperti Badan Eksekutif Mahasiswa, Dewan Perwakilan Mahasiswa dan Unit Kegiatan Mahasiswa.

\section{Price}

Harga merupakan jumlah uang yang harus dibayarkan konsumen untuk mendapatkan suatu produk guna memenuhi kebutuhan serta suatu keinginan yang belum terpuaskan. Peranan harga tidak lepas dari proses jual beli suatu produk atau jasa, dan harga adalah sejumlah uang yang harus dikeluarkan oleh konsumen untuk mendapatkan produk atau jasa yang akan dibelinya guna memenuhi kebutuhan dan keinginannya.

Penjualan produk maupun jasa pasti akan ada suatu nilai atau harga tersendiri, pada umumnya kampus mempuyai suatu kebijakan masing-masing guna memenuhi perputaran keuangan dikampus tersebut, walaupun bagi kampus negeri ada aturan yang telah disepakati, akan tetapi bagi kampus swasta mempunyai otoritas mengenai proses kesepakatan harga atau nilai jualnya itu sendiri, kampus Universitas Teknologi Sumbawa mempuyai cara pembayaran yang sama bagi semua mahasiswa regular dengan nomial yang berbeda-beda pada setiap fakultasnya dan angkatan masuknya, selain itu bagi angkatan 2017 dan 2018 kampus
Universitas Teknologi Sumbawa menyiapkan beberapa jenis beasiswa yaitu beasiswa Tau Samawa, Bidikmisi Regular, dan Bidikmisi Aspresiasi, dan bagi angkatan 2019 mengunakan sistem tingkatan 1, 2 dan 3 dan itu semua disesuaikan dengan nilai yang didapatkan setelah keluar hasil dari ujian masuk kampus. Salah satu kendala masyarakat Sumbawa pada umumnya dimana tingkat ekonominya pada rata-rata menengah ke bawah sehingga menjadi kendala ketika anaknya akan melanjutkan ke pendidikan tinggi yang kita ketahui bersama bahwa biaya untuk masuk kampus bukan lagi seperti saat masuk ke sekolah, dengan asumsi sebagian besar orang tua mahasiswa adalah petani yang penghasilannya hanya berkisar saat musim panen tiba dan tidak menentu dengan keadaan yang saat ini.

\section{Place}

lokasi adalah suatu keputusan perusahaan untuk menentukan tempat usaha, menjalankan kegiatan usaha atau kegiatan operasional, dan mendistribusikan barang atau jasa yang menjadi kegiatan bisnisnya kepada konsumen. Pentingnya lokasi bagi perusahaan atau pengusaha sangat mempengaruhi keputusan sasaran pasar dalam menentukan keputusan pembeliannya.

Kampus sudah pasti mempunyai lokasi untuk menjalankan jasa pendidikannya dan untuk menjadi bukti bahwa kampus itu benar adanya, Kampus Universitas Teknologi Sumbawa sendiri berlokasi di Desa Batualang, Kecamatan Moyo Hulu, Jarak yang di tempuh dari pusat kota kurang lebih $15 \mathrm{KM}$, untuk lingkungan sekitar kampus benar-benar masih alami dan bahkan dari jalan utama tidak terlihat ada sebuah kampus yang berdiri

\section{Promotion}

Promosi adalah kegiatan guna memberitahukan produk atau jasa yang hendak ditawarkan kepada calon konsumen yang dijadikan target pasar. Kegiatan promosi idealnya dilakukan secara berkesinambungan melalui beberapa media yang dianggap efektif dapat menjangkau pasar, baik cetak maupun elektronik, namun pemilihannya sangat tergantung pada target pasar yang hendak dituju.

Berbagai cara kampus akan melakukan sesuatu cara promosi agar menarik minat para calon mahasiswanya, seperti melakukan promosi dari satu sekolah kesekolah lainnya, memasang spanduk atau baliho diberbagai wilayah, menjalankan media sosial yang saat ini sangat digunakan oleh anak muda, kemudian kerjasama dengan perusahaan dalam menawarkan beasiswa, mengadakan Lomba-lomba dan 


\section{JURNAL MANAJEMEN DAN BISNIS VOL. 02 NO.02 2019}

Jurnal.uts.ac.id

memberikan hadiah bagi juara langsung mendapatkan beasiswa masuk kampus, kemudian melaksanakan kerjasama dengan sekolah-sekolah untuk mencari dan mendapatkan calon mahasiwa berprestasi agar langsung di arahkan ke kampus, memasarkan prestasi yang telah kampus dapatkan, selanjutnya Rektor dan Dosen melakukan kunjungan atau kerjasama dengan kampus luar negeri maupun mengikuti konfrensi internasional, kemudian melaksanakan berbagai kerjasama dalam bidang sosial dengan desa pada wilayah sekitar kampus tersebut, selanjutnya memperlihatkan alumni kampus yang telah berhasil pada bidangnya masing-masing, dan yang terakhir kekuatan pemasaran dari word of mouth yang bisa dilakukan ketika kampus telah memberikan satu dampak positif bagi semua kalangan dalam wilayah tersebut.

Begitu pula dengan kampus Universitas Teknologi Sumbawa yang mengunakan hal yang sama seperti yang telah dibahas sebelumnya, seperti yang di katakan oleh hampir semua informan bahwa kampus Universitas Teknologi Sumbawa melakukan berbagai cara promosi pada wilayah Kabupaten Sumbawa sendiri

\section{People}

Manusia merupakan pelaku yang memainkan peranan penting dalam penyajian jasa sehingga dapat mempengaruhi persepsi pembeli dalam mengambil sebuah keputusan dalam menentukan dan memilih kampus Universitas Teknologi Sumbawa.

Masyarakat akan mengenal sesuatu itu karena ada hal yang dikenal, ketika kita berbicara tentang kampus maka tidak lain yaitu Rektor, Dosen, Staf, Alumi dan Mahasiswa Berprestasi, dengan maksud untuk memikat calon mahasiswa dan Orang Tuanya, dengan salah satunya dengan mengenal siapa saja didalam kampus tersebut. peneliti menyebut yaitu penokohan atau sesosok orang yang bisa menarik calon mahasiswa untuk menjadi bagian dari kampus Universitas Teknologi Sumbawa, bahkan dalam media promosi mengenalkan sosok Rektor Muda lulusan dari S-3 Korea Selatan, Wakil Rektor dari ITS, Trisakti dan Unram, Kemudian Dekan fakultas yang berfariasi lulusan dan pengalaman dalam dunia pendidikan, dan dosen berasal dari lulusan kampus ternama lainnya seperti UGM, UB, UI, ITB, UN Malang, IPB, kampus jepang, Polandia, Taiwan dan banyak lagi, kampus Universitas Teknologi Sumbawa bisa dikatakan menjadi satu-satunya kampus yang dikenal diwilayah Sumbawa dengan pengajar dari lulusan kampuskampus ternama dilndonesia bahkan lulusan dari kampus ternama diluar negeri.

Kemudian dari segi mahasiswa dengan prestasi-prestasi yang telah membuktikan bisa menembus pada tingkatan regional, nasional maupun internasional maka dari situlah awal dari sebuah penokohan, semakin menyakinkan bagi para calon mahasiswa yang akan me

milih kampus Universitas Teknologi Sumbawa, kemudian ditambah dengan latar belakang pendiri dan Ketua Yayasan Dea Mas lulusan dari kampus Universitas Indonesia dan dari Kampus diluar negeri bahkan saat ini beliau menjadi Gubernur Nusa Tenggara Barat maka akan semakin menyakinkan calon mahasiwa beserta keluarganya untuk memilih kampus Universitas Teknologi Sumbawa

\section{Physical Evidence}

Physical Evidence menurut Kotler (2011) adalah bukti yang dimiliki oleh penyedia jasa yang ditujukan kepada konsumen sebagai usulan nilai tambah konsumen dengan kata lain bukti fisik adalah keadaan atau kondisi yang terjadi didalamnya.

Pada awal mulanya mengetahui Universitas Teknologi Sumbawa hanya sekedar dari foto-foto yang menyebar diseluruh media cetak maupun disebar pada media elektronik yang digunakan oleh pihak Penerimaan Mahasiswa Baru dan Hubungan Masyarakat Universitas Teknologi Sumbawa, dimana memasarkan dengan foto yang tepat agar bisa menarik minat para calon mahasiswa khususnya mahasiswa asal Kabupaten Sumbawa sendiri, baik dengan foto gedung perkuliahan, foto ruang penunjang pembelajaran, lokasi yang nyaman dan asri serta tatanan yang rapi.

\section{Process}

Proses adalah serangkaian langkah sistematis, atau tahapan yang jelas dan dapat ditempuh berulangkali, yang dimana untuk mencapai hasil yang diinginkan. jika ditempuh, pada setiap tahapan itu dilakukan secara konsisten akan mengarah pada hasil yang diinginkan.

Proses menjadi mahasiswa memerlukan tahapan atau disebut prosedur dimulai dari pendaftaran, ujian Tulis, Ujian wawancara hingga sampai dinyatakan masuk atau lulus ujian masuk oleh pihak kampus Universitas Teknologi Sumbawa, seperti diketahui bersama sangat banyak pendaftar yang menginginkan masuk ke jenjang perguruan tinggi dan disitu ada persaingan antara calon mahasiswa untuk merebutkan kursi atau kuota masuk dalam kampus Universitas Teknologi Sumbawa

\section{Budaya}

Faktor budaya memberikan pengaruh paling banyak dalam setiap perilaku konsumen, oleh karena itu harus mengetahui peranan yang akan dimainkan oleh faktor budaya, sub-budaya dan kelas sosial konsumen, budaya merupakan 


\section{JURNAL MANAJEMEN DAN BISNIS VOL. 02 NO.02 2019}

\section{Jurnal.uts.ac.id}

kumpulan dari nilai-nilai dasar, persepsi, perilaku dan keinginan yang dipelajari dari keluarga dan lembaga yang penting lainnya

1. Kelas ekonomi menengah ke bawah

2. Membebani orang tua dari segi biaya

3. Sosial

Faktor sosial juga dapat mempengaruhi perilaku konsumen, seperti keluarga, kelompok kecil, peranan dan status sosial

Berbicara tentang faktor sosial sangat dekat dengan emosional antar individu, seperti halnya dalam penelitian ini yang mendapatkan beberapa alasan

1. Orang tua tidak mau jauh dari anak

2. Ingin bersama-sama kawan yang telah lama dikenal

3. Diajak oleh sodara atau keluarga

\section{Psikologi}

Faktor psikologis terdapat empat hal yaitu aspek motivasi, persepsi, pengetahuan dan kepercayaan, pada point ini lebih terhadap emosional diri mahasiswa sendiri ketika memutuskan melanjutkan kuliah di Universitas Teknologi Sumbawa.

1. Mempunyai persepsi yang tinggi sebelum masuk dunia kampus

2. Tekanan oleh keluarga yang tidak memperbolehkan kuliah jauh

3. Menjadi pilihan terakhir karena tidak lulus di kampus lain

4. Menjadi pilihan utama karena ingin membangun daerah dengan kuliah di Universitas Teknologi Sumbawa

5. Percaya karena Dosen Universitas Teknologi Sumbawa berasal dari kampus dengan kualitas terbaik

6. Menjadi tolak ukur kampus di wilayah Kabupaten Sumbawa

Seluruh informan penelitian skripsi ini dengan penuh keyakinan menyatakan akan menyelesaikan hingga akhir di Universitas Teknologi Sumbawa dan mereka semua menyatakan dalam tingkat kepuasan yang cukup baik, baik dari pengajaran dan interaksi seluruh civitas akademika Universitas Teknologi Sumbawa.

\section{KESIMPULAN dan Saran \\ Kesimpulan}

Telah dilakukan penelitian dan pembahasan yaitu Analisis Faktor Faktor yang Mempengaruhi Keputusan Mahasiswa Asal Kabupaten Sumbawa Dalam Memilih Perguruan Tinggi Universitas Teknologi Sumbawa. Adapun kesimpulan dari penelitian ini yaitu :

1. Produk yang ditawarkan oleh Universitas Teknologi Sumbawa cukup berbeda dari segi program studi yang langka khususnya di wilayah Bali-Nusa Tenggara
2. Harga atau pembiayaan dalam jasa pendidikan di kampus Universitas Teknologi Sumbawa sangat berbeda dengan kampus di wilayah Sumbawa sendiri maka dari situ kampus mempunyai dari tarik yang berbeda bagi calon mahasiswanya. Kampus Universitas Teknologi Sumbawa juga menawarkan berbagai jenis beasiswa untuk mahasiswanya dengan melihat kondisi masyarakat Sumbawa yang mayoritas pada tingkatan ekonomi menengah ke bawah

3. Lokasi yang ditawarkan oleh kampus Universitas Teknologi Sumbawa sangat unik dan berbeda, kampus yang terletak dibawah bukit olat maras, jauh jarak tempuh dari pusat kota dan dikelilingi oleh hamparan sawah, kampus yang memilki karakteristik berbeda membuat sebagian orang akan semakin tertarik karena mencari ketenangan dan kenyamanan dalam mempelajari sebuah ilmu

4. Pemasaran kampus Universitas Teknologi Sumbawa telah dilakukan dengan berbagai cara untuk menarik dan mengajak calon mahasiswa khususnya berasal dari kabupaten Sumbawa, kemudian setelah melihat jumlah dari setiap tahunnya yang meningkat berbarti benar adanya kemajuan dalam pemasaran di wilayah kabupaten Sumbawa

5. Manusia atau tokoh didalam kampus Universitas Teknologi Sumbawa, masyarakat dan calon mahasiswa benar-benar melihat kualitas dari calon pengajarnya saat kuliah nanti dan kampus Universitas Teknologi Sumbawa itu sendiri telah membuktikan walaupun kampus di timur tetapi kualitas Dosen tidak perlu diragukan kembali karena berasal dari lulusan kampus ternama di Indonesia bahkan dari luar negeri

6. Bukti fisik atau infrastruktur yang disediakan oleh kampus masih kurang sehingga menurut penuturan seorang informan yang telah ditelaah oleh peneliti bahwasannya kampus Universitas Teknologi Sumbawa masih kurang begitu fokus memperhatikan terhadap fasilitas utama yang menunjang mahasiswa

7. Proses untuk menjadi bagian dari mahasiswa Universitas Teknologi Sumbawa menurut penelitian yang dilakukan oleh peneliti mengatakan bahwa hampir sebagain besar mengatakan masuk atau ujian kampus 
ini masih sangat mudah bahkan hampir tidak ada hambatan

8. Dari hubungan segi manusia atau individu dengan media promosi sangat berpengaruh karena calon mahasiswa dan orang tuanya setelah melihat dari mahasiswanya, alumni dan para pengajar sangat erat dikarenakan, dengan mempromosikan atau mengenalkan 3 point tersebut menambah kepercayaan calon konsumen itu sendiri sehingga akan meningkat masyarakat Sumbawa yang mendaftar ke kampus UTS.

9. Dari wawancara yang dilakukan kampus UTS mampu mengungguli di wilayah Sumbawa namun masih kalah saing dengan masalah akreditasi di wilayah NTB khususnya

\section{Saran}

Dalam penelitian ini perlu kiranya disampaikan beberapa saran. Adapun saran yang membangun untuk kemajuan pada umumnya kepada Universitas Teknologi Sumbawa maupun bagi pihak-pihak didalammya yaitu oleh bagian Hubungan Masyarakat dan Unit Pelaksana Teknis Penerimaan Mahasiswa Baru yang memerlukan yaitu :

1. Dari penelitian melihat bahwa kampus Universitas Teknologi Sumbawa masih menjadi kampus yang dipandang sebelah mata oleh mahasiswa asal Kabupaten Sumbawa pada awalnya dikarenakan masalah akreditasi kampus sehingga kampus dapat sesuatu yang bisa menggantikan dengan bahasan yang lain sehingga masalah akreditasi bisa di sampingkan.

2. Infrastruktur penting harus lebih diutamakan seperti jalanan menuju kampus yang masih banyak ditemui berlubang, demi keselamatan berkendara seluruh civitas akademi Universitas Teknologi Sumbawa.

3. Kampus harus lebih mendorong segala kegiatan mahasiswa yang mengadakan lomba bagi siswa SMA karena dengan cara tersebut dapat mengenalkan kampus Universitas Teknologi Sumbawa, sekaligus dapat memperlihatkan kualitas dan kapasitas dari mahasiswa secara langsung.

4. Seseorang atau masyarakat ketika pertama kali melihat sebuah kampus akan lebih nyaman ketika melihat kerapian sebuah kampus tersebut, maka peneliti menyarankan guna merapikan seluruh lahan parkiran yang berada di lingkungan kampus Universitas Teknologi Sumbawa.
5. Beasiswa harus lebih selektif karena dari beberapa informan tidak mendapatkan beasiswa pada porsinya bahkan mahasiswa yang biasa-biasa saja yang mendapatkan beasiswa penuh.

6. Dalam proses masuk dan mendapatkan beasiswa tidak hanya melihat nilai saat ujian masuk saja tetapi melihat prestasi saat sekolah sebelumnya karena dikemudian hari kampus dapat mengembangkan dan menjadi investasi terbaik yang dimiliki oleh sebuah kampus.

7. Dilihat dari tahun 2015 hingga saat ini prestasi mahasiswa Universitas Teknologi Sumbawa masih naik turun sehingga saat penelitian skripsi ini ketika ada pertayaan prestasi apa yang kamu ketahui saat waktu masih di SMA dahulu pasti jawabannya yaitu lomba IGEM (International Genetically Engineered Machine) oleh Mahasiswa Bioteknologi angkatan 2013, maka dari situ kampus mempunyai tugas berat untuk membantu dalam peningkatan dalam prestasi mahasiswa Universitas Teknologi Sumbawa.

8. Dari wawancara yang telah dilakukan menyatakan bahwa media promosi yang masih sangat berpengaruh yaitu dengan penawaran beasiswa yang melihat segi ekonomi masyarakat Sumbawa yang berlatar belakang petani, dari ini menjadi satu saran agar menarik mahasiswa asal Kabupaten Sumbawa.

9. Kampus kan menjadi merubah pola pikir masyrakat Sumbawa ketika kampus UTS dapat menjadi kampus yang siap memberikan ruang kapada masyarakat Sumbawa untuk melanjutkan pendidikan dan menfasilitasi untuk kuliah diluar atau menyalurkan ke lapangan kerja setelah menyelesaikan di kampus UTS.

10. Ketika kampus UTS tidak lagi menawarkan beasiswa maka kampus UTS bisa menawarkan dari segi prestasi dan juga menawaran akreditasi karena dengan sebuah akreditasi masyarakat akan langsung percaya kapada kampus UTS dapat menjadi prioritas untuk mendapatkan lapangan kerja maupun ketika ingin melanjutkan jenjang pendidikan selanjutnya.

\section{DAFTAR PUSTAKA}

Alma, Buchari. (2013). Manajemen Pemasaran dan Pemasaran Jasa, Penerbit Alfabeta, Bandung

Adrian, Payne, (2014). Pemasaran Jasa: The Essence of Service Marketing. Andi, Yogyakarta. 
Fandy, Tjiptono, Ph.D. (2015). Strategi Pemasaran, Edisi 4, Penerbit Andi, Yogyakarta

Fandy, Tjiptono, (2014). Pemasaran Jasa (Prinsip, Penerapan, Penelitian). Yogyakarta. Andi.

Gunawan, Iman, (2013). Metode Penelitiaan Kualitatif :Teori dan Pratilik. Jakarta: Bumi Aksara.

Herry A. Buchory dan Djaslim Saladin, (2010). Manajemen Pemasaran (Teori, Aplikasi, dan Tanya Jawab). Bandung: Linda Karya.

Husein Umar, (2005). Metode Penelitian. Jakarta : Salemba Empat

Kotler, Philip and Gary, Armstrong, (2012). Prinsip-prinsip Pemasaran. Jilid 1. Jakarta: Erlangga.

Kotler, Philip dan Amstrong, Gary, (2014). Principles of Marketing, Jilid 1 Jakarta : Erlangga.

Kotler, Philip dan Gary Armstrong. (2010). Pinsip-prinsip Pemasaran (Edisi 13). Jilid 1 jakarta : Erlangga

Kotler, Philip and Gary, Amstrong, (2016). Prinsip-prinsip Pemasaran. Edii13. Jilid 1. Jakarta : Erlangga

Lupiyoadi, Rambat dan A. Hamdani, (2011). Manajemen Pemasaran Jasa. Edisi Dua. Jakarta : Salemba Empat.

Margaretha dan Nilo. (2016). Analisis Pemilihan PTS di Jakarta dengan Fishbein dan Biplot. ( Pengesahan Proposal Innovation Award 2016. Bina Nusantara)

Moleong, Lexy J, (2014). Metodologi Penelitian Kualitatif, PT Remaja Rosdakarya, Bandung.

Nugroho, R.,\& Japarianto, E. (2013). Pengaruh Product, Promotion, Place, Price, People, dan Physical Evidence Terhadap Tingkat (Kunjungan di Coffee Cozies Surabaya.Jurnal Manajemen Pemasaran Petra,Volume 1, No. 2, 1-9.)

Punaji Setyosari.(2010). Metode Penelitian Pendidikan dan Pengembangan.Jakarta : Kencana.

Setiadi, N.J. (2010). Perilaku Konsumen. Jakarta: Kencana

Sejarah kampus Universitas Teknologi Sumbawa yang bersumber dari http://www.UTS.ac.id

Suharsimi, Arikunto,(2010). Penelitian Suatu Pendekatan Praktik. Jakarta: PT. Rineka Cipta

Sugiyono (2011). Metode Penelitian Kuntitatif $K$ ualitatif dan $R \& D$. Alfabeta Alih bahasa Bob Sabran. Jakarta :

Penerbit Erlangga.

Sugiyono. (2015). Metode Penelitian Pendidikan. Bandung: Alfabeta

Sugiyono. (2016). Metode Penelitian Kuantitatif, Kualitatif dan $R \& D$. Bandung: PT Alfabet.
Stanton, William J. (2013). Prinsip Pemasaran. Alih Bahasa oleh Buchari Alma. Jilid Satu. Edisi Kesepuluh. Jakarta : Erlangga.

Tiga dimensi dasar pembentuk IPM bersumber dari http://www.bps.go.id

United States of America: Pearson.

Wijaya, D, (2012). Pemasaran Jasa Pendidikan, Jakarta : Salemba Empat.

$$
1 .
$$

